\title{
THE DEVELOPMENT OF THE MUCOUS MEMBRANE OF THE LARGE INTESTINE AND VERMIFORM PROCESS IN THE HUMAN EMBRYO
}

\author{
FRANKLIN PARADISE JOHNSON \\ From The Harvard Medical School, Boston \\ TWENTY-NINE FIGURTS
}

The following paper is the second of a series of studies concerning the mucous membrane of the digestive tract. The first (Johnson '10) dealt with the development of the oesophagus, stomach and small intestine. The present paper is devoted entirely to the large intestine, and includes all its parts except the lower portion of the rectum. It is followed by an account of the effects of distention upon the small and large intestines of various animals. It is proposed to publish later an account of the development of the anal portion of the rectum, work upon which is nearly completed. The study of the mucous membrane of the digestive tract was proposed to me by Dr. F. T. Lewis in 1909, and as the work has progressed, I have received from him many valuable suggestions.

The development of the large intestine is of special interest owing to the variety of pictures its mucosa presents. Relatively simple in the beginning and again in the adult as compared with other portions of the alimentary canal, the mucosa passes through a number of complicated changes before it attains its full development. To begin with, the smooth epithelial tube of the large intestine develops more or less regular longitudinal folds. These folds, as will be subsequently described, are later replaced by villi. Still later the villi themselves disappear. Meanwhile, glands are forming, and when the villi have entirely faded out, 
the large intestine reaches its adult condition. The presence of 'transitory' villi has long been known, being first described by Barth in 1868 . Since then they have been studied by a number of investigators, and several opinions have arisen in regard to their manner of disappearance. However, most of the former work has been done on lower animals, no one account giving a complete history of the changes that take place in the human embryo.

In the present paper an attempt is made to describe in some detail the mucosa of the large intestine and vermiform process in a number of consecutive embryonic stages, and to present a series of pictures made from wax reconstructions illustrating the descriptions. The following account deals strictly with the human embryo, and is based on a number of carefully selected stages. The embryos used are arbitrarily divided into two groups;--the younger stages, which were sectioned whole; and the older stages, from which the various portions of the digestive tube were removed from the embryo and sectioned separately. The younger stages used were all obtained from the Harvard Embryological Collection. They are as follows:

\begin{tabular}{c|c|l}
\hline CROWN-RUMP LENGTH & H.E.C. EERIES NO. & \multicolumn{1}{|c}{ FIXATION } \\
\hline$m m$. & & \\
7.5 & 256 & Zenker's fluid \\
10.0 & 1000 & Zenker's fluid \\
16.0 & 1322 & Picro-sulphuric \\
22.8 & 871 & Alcohol and formalin \\
30.0 & 913 & Formalin \\
37.0 & 820 & Parker's fluid \\
42.0 & 838 & Zenker's fluid \\
\hline
\end{tabular}

The older stages were obtained from three different collections. I wish here to express my thanks to Prof. C. S. Minot, Harvard Medical School, Prof. C. 'M. Jackson, University of Missouri, and Prof. Franz Keibel, Freiburg i/Br., for allowing me the privilege of cutting out what portions of their embryos I desired for my work. The list of older stages used is as follows: 


\begin{tabular}{|c|c|c|c|}
\hline CROWN-BUMP LENGTE & FIXATION & COLLECTION & SERTES NO. \\
\hline$m m$. & & & \\
\hline 50 & Zenker's fluid & Keibel & \\
\hline 55 & Alcohol & Minot & 249 \\
\hline 58 & Zenker's fluid & Keibel & \\
\hline 65 & Zenker's fluid & Keibel & \\
\hline 70 & Alcohol & Keibel & \\
\hline 73 & Picro-sulphuric & Minot & 116 \\
\hline 75 & Alcohol & Minot & 110 \\
\hline 88 & Formalin & Jackson & 137 \\
\hline 99 & Alcohol & Minot & 340 \\
\hline 110 & Formalin & Jackson & 143 \\
\hline 120 & Zenker's fluid & Minot & 342 \\
\hline 140 & Formalin & Jackson & 263 \\
\hline 170 & Formalin & Jackson & 222 \\
\hline 187 & Formalin & Minot & 315 \\
\hline 190 & Formalin & Jackson & \\
\hline 200 & Formalin & Jackson & 89 \\
\hline 240 & Mïller's fluid & Minot & 186 \\
\hline 320 & Formalin 1 & Jackson & 16 \\
\hline Birth ${ }^{2}$. & Zenker's fluid & Minot & 345 \\
\hline Birth $^{3} \ldots \ldots \ldots \ldots$ & Zenker's fluid & Minot & 341 \\
\hline Two wecks child $4 .$. & Zenker's fluid & Minot & \\
\hline
\end{tabular}

1 First injected with a mixture of phenol, alcohol, glycerine, and formalin

${ }^{2}$ Premature birth at seven (?) months. Lived thirty minutes

${ }^{3}$ Normal fetus at birth

4 Premature at seven months. Lived two weeks

\section{THE LARGE INTESTINE}

\section{Early development}

In an embryo of $7.5 \mathrm{~mm}$. the large intestine, like the oesophagus, stomach, and small intestine of the same embryo, is a simple tube of epithelium surrounded by mesenchyma. It is continuous, without demarction, with the small intestine above, and with the urogenital sinus below. Its cephalic end is indistinctly indicated by a slight swelling, which is regarded by Lewis ('11) as the beginning of the vermiform process. This swelling, which I will designate by the term 'colie ampulla' (ampulla coli), is spindle-shaped and has a diameter (measured from side to side in its widest place) of $0.07 \mathrm{~mm}$. Below the swelling the tube becomes markedly narrower. In its narrowest portion it 
measures but $0.04 \mathrm{~mm}$. in diameter. As the urogenital sinus is approached the epithelial tube again increases in size and becomes compressed from side to side. This enlargement passes insensibly over into the epithelium of the cloaca.

The walls of the epithelial tube also vary in thickness. Above, where it is broadest, the walls have a thickness of about 0.028 $\mathrm{mm}$. and are composed of cells which have no distinct cell boundaries. Three rows of oval nuclei are discernible. In the narrower middle portion the walls average about $0.017 \mathrm{~mm}$. in thickness, and show only two rows of nuclei. Where the tube is expanded in the cloacal region, the epithelium is approximately of the same thickness as in the colic ampulla. The lumen in most places is a narrow slit-like cleft, larger in the extremities than in the mid-region of the large intestine, but everywhere present and patent. It communicates with the larger lumen of the cloaca, but cannot be traced through this to the outside because of the presence of the cloacal membrane.

In an embryo of $10 \mathrm{~mm}$. the large intestine presents practically the same relations, but shows a marked increase in size. The colic ampulla, which is now situated well out in the coelom of the umbilical cord, measures alout $0.33 \mathrm{~mm}$. in diameter, and has an epithelium $0.045 \mathrm{~mm}$. in thickness. A slight budlike protuberance of almost the same size as the swelling itself, arises from it, and extends into the mesenchyma. Followed caudally, the epithelial tube of the large intestine quickly diminishes in size, and continues of small size until the region of the rectum is reached. Here it presents another spindle-shaped swelling. This swelling is connected with the cloaca by a short and narrow tube. The upper narrow portion of the epithelial tube measures about $0.07 \mathrm{~mm}$. in diameter, and its wall is $0.028 \mathrm{~mm}$. thick. The swelling is $0.12 \mathrm{~mm}$. in diameter, and has a wall thickness of $0.036 \mathrm{~mm}$. The lumen is continuous as far as the cloacal membrane where it is closed off from the exterior.

At $16 \mathrm{~mm}$. the colic ampulla is similar in form but larger than in the preceding stages, being now $0.17 \mathrm{~mm}$. in diameter. It is directly continued into the vermiform process, which is found 
in the umbilical cord, pointing away from the embryo. Large at its base where it joins the colic ampulla, the vermiform process tapers gradually towards its blind end. The before-mentioned narrow portion of the large intestine, now $0.09 \mathrm{~mm}$. in diameter, has increased much in length. The lumen of the lower end of the digestive tube no longer leads into the cloaca, but opens to the outside by an extremely small aperture.

In the further course of its development, the swelling in the rectal region becomes much larger, and longitudinal folds make their appearance. These longitudinal folds increase in numbers, and are markedly constant in position in all the older stages. Just what is the fate of these folds I am unable at the present time to state precisely, but it is not improbable that they give rise to the rectal columns (columnae rectales Morgagni) while the spaces between them no doubt develop into the rectal sinuses (sinus rectales). A discussion of the further development of this portion of the digestive tract, however, has been omitted from the present paper.

\section{The development of longitudinal folds}

In an embryo of $22.8 \mathrm{~mm}$. one sees for the first time a change in the form of the epithelium. In the colic ampulla, which now has a diameter of $0.20 \mathrm{~mm}$., the epithelium shows three low longitudinal ridges on its inner surface. These ridges also extend for short distances into the colon and vermiform process.

It becomes necessary at this point to explain the manner in which the terms 'ridges' and 'folds' have been used throughout the remainder of this article. The term 'ridge' has been employed to designate a thickening of the epithelium which projects into the lumen. It must have no corresponding indentation on its under surface into which mesenchyma would extend. By a 'fold' is meant a projection with an indented basal surface, into which the underlying mesenchyma protrudes. This distinction is desirable, as its usage makes it possible to explain in few words the shape of the basal surface of the epithelium along with that of its free surface. 
The epithelium in the embryo under consideration $(22.8 \mathrm{~mm}$.) varies in thickness in different regions. In the colic ampulla and vermiform process it is $0.056 \mathrm{~mm}$. thick and shows three to four rows of nuclei. In the remainder of the colon down to the rectal ampulla, it is only $0.034 \mathrm{~mm}$. in thickness and shows but two to three rows of nuclei. At no place are the boundaries between the cells distinct, but the free and basal surfaces are well marked.

In an embryo of $30 \mathrm{~mm}$. the whole of the vermiform process and the valve of the colon lie in the coelom of the umbilical cord. An examination of the interior of the colon in this region shows the beginnings of two to three epithelial ridges. These vary in height, the epithelium being $0.070 \mathrm{~mm}$. thick, measured through the summit of the largest ridge, while in the depressions between them, it is only about $0.028 \mathrm{~mm}$. thick. Three or four rows of nuclei can be made out. The remainder of the colon has an average diameter of $0.15 \mathrm{~mm}$. Throughout its great length the epithelial tube is still cylindrical in shape, having a wall $0.048 \mathrm{~mm}$. in thickness. Three or four rows of nuclei are present.

At $37 \mathrm{~mm}$. the whole of the vermiform process still lies in the umbilical cord. The epithelial ridges are higher than in the former stages. In the base of the vermiform process there are four of these, in the middle only three; in the beginning of the colon, three or four. The highest ridge measures about $0.10 \mathrm{~mm}$. in height and has three or four rows of nuclei. Between the ridges the epithelium is only $0.042 \mathrm{~mm}$. thick and shows but two or three nuclear layers. The remainder of the large intestine gradually decreases in size when followed caudally. The portion which is to become the ascending colon is $0.27 \mathrm{~mm}$. in diameter; the transverse $0.22 \mathrm{~mm}$.; and the descending colon $0.18 \mathrm{~mm}$. The epithelium is about $0.056 \mathrm{~mm}$. thick in all these portions. A few vacuoles, such as have been found in the epithelial walls of the stomach and oesophagus are present in the colon of this embryo.

In an embryo of $42 \mathrm{~mm}$. the ridges of the epithelium are in part replaced by true longitudinal folds. In the vermiform proc- 
ess and ascending colon three to four of these are present; in the transverse colon two to three; in the greater part of the descending colon three; while in the remainder of the descending colon five to six more irregular ones. These folds vary in height from 0.014 to $0.028 \mathrm{~mm}$. The epithelium is thicker on their crests than between them. It presents an appearance which is largely in accordance with a condition which Patzelt ('83) has found in the large intestine of the cat embryo. He describes two types of cells. In the corners of the star-shaped lumen the cells are short and broad, and have basal nuclei which stain intensely with haemotoxylin. The cells of the second type are found on the tops of the folds. They are longer, finely granular, and somewhat denser. Their nuclei are long-oval or drop-shaped and stain more intensely than those of the first type. The former groups of cells he states are the first anlagen of the Lieberkühn glands; the latter of the villi. The epithelium of the large intestine of the embryo under consideration $(42 \mathrm{~mm}$.) has been described and pictured by Lewis ('11). The two types of cells are found arranged in separate groups, but, however, are not as distinct as those of the cat described by Patzelt.

In the ascending colon of an embryo of $50 \mathrm{~mm}$., the epithelial tube has a diameter of about $0.23 \mathrm{~mm}$., and shows four distinct longitudinal folds. These are, as shown in figure 12 , rounded on their tops, and are of different heights, the largest measuring about $0.06 \mathrm{~mm}$. In the piece of ascending colon sectioned for study, which measures about $0.7 \mathrm{~mm}$. in length, the epithelial tube changes but little in shape, the four distinct longitudinal folds running throughout. The epithelium, which has an average thickness of $0.050 \mathrm{~mm}$., is columnar, and, as seen in sections ten microns thick, is apparently stratified, being composed of two or perhaps three, layers of cells. The nuclei, which are oval in shape, are all placed in a zone midway between the free and basal surfaces of the epithelium, there being a clear zone of protoplasm on either side. A definite cuticular border is everywhere present on the free surface of the epithelium. Two distinct types of cells are not visible. Outside of the epithelium is a zone of loose mesenchyma which is bounded by a thin layer 
of myoblasts, the circular layer of the muscularis. This is in turn bounded by a layer of mesenchyma and surrounding the whole, except at its mesenteric attachment, a distinct serous epithelium is seen.

In passing ab-orally from the ascending colon into the transverse colon, one of the four longitudinal folds just described drops out, while a second becomes so much reduced in size that it is scarcely recognizable as a fold (figs. 1 and 13). The two remaining folds are distinct and about $0.06 \mathrm{~mm}$. in height. The epithelial tube has a diameter of about $0.27 \mathrm{~mm}$. The remaining features of this portion of the large intestine are similar to those of the ascending colon.

\section{First appearance of goblet cells}

In the iliac colon (50 mm. embryo), the epithelial tube as a whole is flattened from side to side. Its greater diameter is $0.36 \mathrm{~mm}$., its lesser $0.18 \mathrm{~mm}$. A considerable change in the condition of folds is evident. They are shallow, irregular, and more numerous than in the ascending and transverse colons. A model of a small portion of this region is shown in figure 14 . The distinction between epithelial ridges and folds is here apparent-only those protuberances, which have indented basal surfaces into which the mesenchyma extends, being considered as true folds. Measured through the ridges the epithelium is in places $0.084 \mathrm{~mm}$. thick, while in the clefts between them, it is only $0.028 \mathrm{~mm}$. thick. The two types of cells described by Lewis in the $42 \mathrm{~mm}$. stage are distinct. A few cells on the ridges have a protoplasm which is clearer than others, and are shaped somewhat like goblet cells. Because these cells in the next few stages take on more and more the appearance of goblet cells until their identity cannot be doubted, I believe them to be goblet cells in a very early stage of differentiation. Voigt ('99) was able to distinguish goblet cells first in the rectum of a human embryo of $70 \mathrm{~mm}$.

The ascending colon of an embryo of $55 \mathrm{~mm}$. has a diameter of $0.45 \mathrm{~mm}$. Ten to twelve longitudinal ridges are found, but 
distinct folds are absent. The ridges are irregular in form and of varying size, the largest being about $0.10 \mathrm{~mm}$. in height. The two types of cells are distinct now in this region of the large intestine, some of which are like those which Patzelt has described as drop-shaped. In many places large vacuoles similar to those described above are found in the epithelium of the ridges.

The epithelial tube of the transverse colon is of the same size as the ascending, and shows six well marked projections into the lumen, two of which are folds. In the upper part of the descending colon, two ridges and two folds are present. In the iliac colon the folds drop out and only ridges are found. When

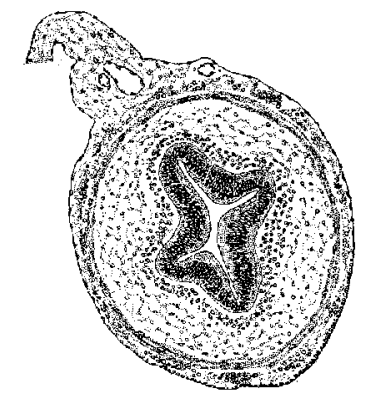

Fig. $1^{1}$ Cross section of the transverse colon of a human embryo of $50 \mathrm{~mm}$. $\times 60$.

followed downward, the descending colon shows more and more ridges and when the sigmoid colon is reached there are as many as ten or twelve. Still more caudally the rectum shows folds which have taken the place of the ridges. In the lower part of the rectum, just above the rectal ampulla, practically all the ridges have been replaced by folds, varying from ten to fourteen in number. The appearance obtained from cross sections, therefore, is somewhat similar to that found in the stomach of the same and slightly older embryos-the clefts in between the ridges corresponding to the gastric pits. The clefts, however, are broader and the colls of the epithelium lining them are more

${ }^{1}$ In this and all remaining text figures certain histological details have been omitted. 
columnar in form than those of the gastric pits. Throughout all these portions of the large intestine the cells on the crests of the ridges differ from those between them. In the rectum the epithelium is distinetly one-layered. On the crests of its folds it presents a number of cells with clear protoplasm and basal nuclei. These presumably are developing goblet cells.

In the colon of an embryo of $58 \mathrm{~mm}$. the epithelial tube is found to be quite similar to that of the $55 \mathrm{~mm}$. embryo just described. It is slightly smaller throughout than in the previous stage, which difference may in part be accounted for by the different kinds of preserving fluids used. In the cephalic end

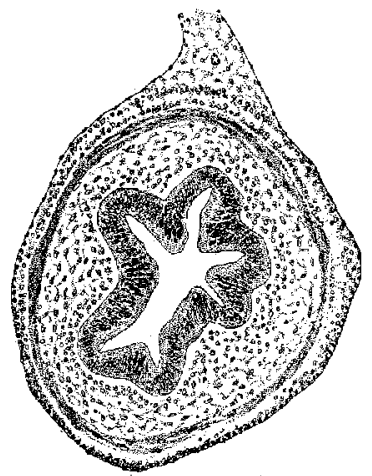

Fig. 2 Cross section of the transverse colon of a human embryo of $58 \mathrm{~mm}$. $\times 60$.

of the ascending colon the epithelial tube has now a diameter of $0.38 \mathrm{~mm}$. and shows numerous ridges and folds as seen in figure 15. More caudally in the ascending colon the epithelium is not so irregular as near the caecum. As seen in sections three folds and one ridge are present. Figure 16 shows a model of this portion of the intestine. It is to be noted that the tops of the longitudinal folds are irregular in form. The diameter of this region of the gut is about $0.36 \mathrm{~mm}$., while the epithelium averages about $0.050 \mathrm{~mm}$. in thickness.

The transverse colon of an embryo of $58 \mathrm{~mm}$. shows six distinct folds, as seen in figure 2. A model of one half of the tube of this region is represented in figure 17. The diameter of the 
epithelial tube averages $0.38 \mathrm{~mm}$. The descending colon (fig. 18) has a diameter of $0.34 \mathrm{~mm}$., is more rounded in shape, being quite similar to the more cephalic part of the ascending colon. The crests of the folds and ridges are, however, not so angular.

\section{First appearance of villi}

In the rectum the epithelial folds have increased in size and give to the lumen a very irregular form. As shown in figure 19 , some of the folds run almost transversely. The presence of transverse folds have bcen noted in the lower portion of the rectum in a number of older embryos as well. Besides folds, here and there are present conical-shaped projections of the epithclium. These represent the first transitory villi of the large intestine.

In a number of places the folds seem to be fused together at their tops, shutting off small rounded spaces. These spaces I have determined from serial sections to be epithelial cysts. They are found in corresponding portions of the rectum of other embryos, but are confined to this region of the large intestine alone. A portion of one of these cysts is shown in figure 19 at $x$. They are described in detail below.

At this point it seems advisable to make the following summary regarding the development of ridges and folds. In the beginning the epithelial tube is cylindrical in shape. The first changes that take place in its form are found in the rectum, where it shows a number of longitudinal ridges. These ridges are the forerunners of folds, for everywhere they later appear as if pushed in from behind by the underlying mesenchyma. Soon afterward ridges and folds are found in the descending colon, the direction of growth being from below upward. However, before these changes have extended into the transverse colon, similar changes are found to be occurring in the ascending colon near to the colic valve. The direction of growth here is opposite that in the descending colon, that is, ab-orally. The transverse colon is, therefore, the last portion of the large intestine to develop folds. Similarly, in a few of the subsequent stages, the transverse colon shows a slight retardation in the 
development of villi and glands as compared with the rectum, descending and ascending colons. However, this retardation is soon overcome by an increased rate in growth, and then conditions found in all parts of the large intestine are quite similar. As a matter of convenience and simplicity, the development of the transverse colon has been described most completely in the remainder of this article, and other portions of the large intestine are described, as far as is possible, from a comparative point of view with respect to it.

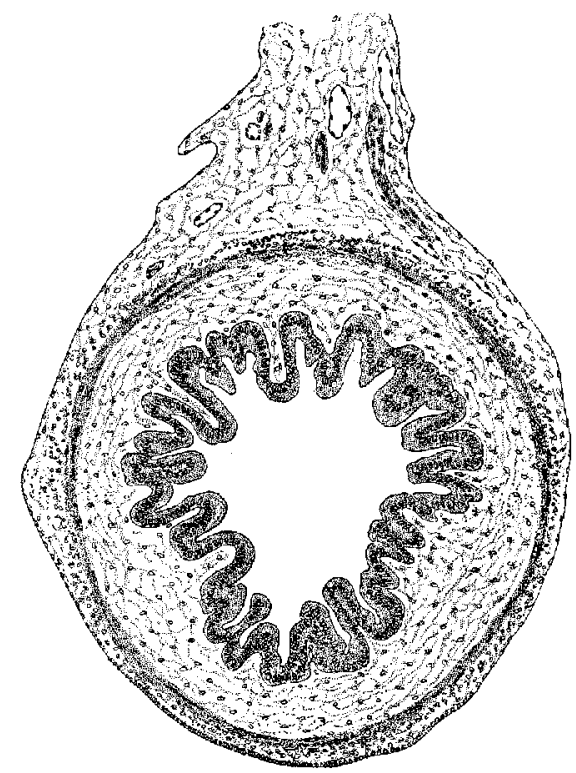

Fig. 3 Cross section of the transverse colon of a human embryo of $65 \mathrm{~mm}$. $\times 60$.

The transverse colon of an embryo of $65 \mathrm{~mm}$. differs considerably from that of the embryo just described. The epithelial tube is circular in section and measures $0.54 \mathrm{~mm}$. in diameter. In transverse section (fig. 3) eighteen to twenty-three projections are seen extending into the lumen. When modelled these projections are seen to be longitudinal folds and villi as shown in figure 20. The villi are everywhere arranged in longitudinal 
rows, suggesting that the folds have become broken up into segments. The folds and villi measure from 0.08 to $0.11 \mathrm{~mm}$. in height and are usually between 0.07 and $0.11 \mathrm{~mm}$. in width at their bases. The epithelium on their tops is distinctly simple columnar in form, and is reduced to $0.019 \mathrm{~mm}$. in thickness; between the folds it is $0.031 \mathrm{~mm}$. thick.

Numerous villi are found in the ascending colon. A comparison of these with those villi in the lower part of the ileum shows that the two are quite similar in form and size. At a short distance from the colic valve, the epithelial walls of the ascending colon become pushed in by three large mesenchymal folds, reducing the lumen to a narrow $Y$-shaped cleft. Here are found folds and villi resembling those shown in figure 20 . The descending colon is smaller in diameter than the transverse, being only $0.45 \mathrm{~mm}$. An examination of its inner surface (fig. 21), shows folds and villi, and what apparently are partially formed villi, about eight to nine rows in all. These are longer than those of the transverse colon, 0.17 to $0.22 \mathrm{~mm}$., but of about the same width. In the sigmoid colon is found a condition comparable to that of the descending colon. However, goblet cells are far more numerous.

\section{First appearance of intestinal glands}

The epithelial tube of the upper portion of the rectum (embryo of $65 \mathrm{~mm}$.) is flattened from side to side, and measures 1.17 by $0.77 \mathrm{~mm}$. in cross section. A very different appearance is presented from that of the transverse colon. The epithelial wall is bent into a number of folds which are closely packed together. Many of these measure as much as 0.27 and $0.36 \mathrm{~mm}$. in height. The bottoms of the spaces between these projections are developing glands. Where they are cut obliquely or in cross section their basal ends are seen to be tubular in form and provided with small round lumina.

Epithelial cysts are more numerous than in the preceding embryo. They represent glands and intervillous spaces which have become closed over at their tops. They show evidences 
of intcrnal pressure by their bulbous appearance and by the flattening of the lining epithelium of the more superficially lying part of the cyst (fig. 11). In many respects these cysts are similar to those found in the vermiform process (compare fig. 11 with figs. 9 and 10) but differ from them by their more superficial position and in that they can rarely be considered to be entirely separated from the surface epithelium. Moreover, they have a different fate from those of the vermiform process. Instead of the cpithelium entirely degenerating, the cyst collapsing, and finally being absorbed, the cysts of the rectum open up with the intestinal lumen and become glands again, at least this interpretation seems justifiable, since the cysts gradually disappear without showing such degenerative processes as are easily recognizable in those of the vermiform process.

The condition found in the transverse colon of an embryo of $70 \mathrm{~mm}$. is not much in advance of the same portion of the large intestine at $65 \mathrm{~mm}$. Its epithelial tube has a diameter of $0.54 \mathrm{~mm}$. The lumen is relatively large and the villi project into it 0.09 to $0.13 \mathrm{~mm}$. The cells forming the epithelium are tall columnar, 0.025 in height, and contain at their basal ends, elongated nuclei. The protoplasm, which stains decidedly yellow with orange- $G$, appears to be mucous in character. Here and there swollen goblet cells are seen. A small portion of the sigmoid colon presents an appearance similar to that described in the rectum at $65 \mathrm{~mm}$. It measures $0.54 \mathrm{~mm}$. by $0.72 \mathrm{~mm}$., and contains folds and villi 0.23 to $0.27 \mathrm{~mm}$. in height. Epithelial glands and cysts are found in large numbers. In the rectum the same conditions are presented, although the epithelial tube is larger and the villi taller $(0.25$ to $0.32 \mathrm{~mm}$.). The latter seem, however, to be so fused together that thoy appear in many places as irregular running folds. Goblet cells are everywhere numerous.

In a well preserved transverse colon of an embryo of $73 \mathrm{~mm}$. the epithelial tube measurcs $0.58 \mathrm{~mm}$. in diameter. The villi and folds, some of which are now 0.22 to $0.23 \mathrm{~mm}$. high, decreaso to a marked extent the size of the lumen. In width the villi show a slight increase, being 0.09 to $0.18 \mathrm{~mm}$. through at their 
bases. The tops of the villi are in many places so closely approximated that it is quite impossible from cross sections of this stage alone to determine whether an actual fusion has or has not taken place. Because of this condition, which I believe to have been brought about by a strong contraction of the muscularis, an attempt to model these villi accurately proved fruitless. From the conditions found in the large intestine, of other embryos of about the same age, however, it would not seem probable that such a thing as an actual fusion had taken place. The epithelium on the tops of the projections is distinctly one-layered and 0.025 to $0.028 \mathrm{~mm}$. thick, while between them it appears

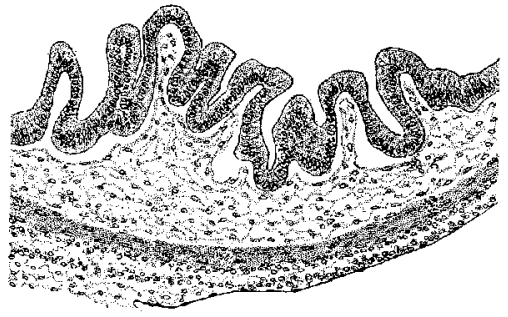

Fig. 4 Cross section of the transverse colon of a human embrya of $88 \mathrm{~mm}$. $\times 60$.

two-layered, and is almost twice as thick, 0.042 to 0.052 . Only the portions of the epithelium in between villi arc provided with distinct basement membrancs.

In the descending colon practically the same conditions are repeated, with the exception that a few more villi are present.

In the transverse colon at $75 \mathrm{~mm}$, even though considerable shrinkage is present, the villi are seen distinctly separated from one another. Other portions of the large intestine from the two last-mentioned embryos were not obtained.

In the transverse colon of an embryo of $88 \mathrm{~mm}$. (fig. 4), are found numerous villi, which are arranged so that they form longitudinal rows. The epithelium on the tops and sides of the villi is similar to that of the preceding stages, being simple columnar in form and containing goblet cells. Between the villi the cells are tall cylindrical and conical in shape, contain oval nuclei 
which scem to be closely erowded together, and stain intensively. These groups of cells form small knob-like projections and are the beginnings of the intestinal glands.

In the ascending, descending, and sigmoid colons, as secn from transverse and longitudinal sections, both villi and the beginuings of glands are distinguishable. The villi gradually increase in length as the large intestine is followed caudally; thus in the ascending colon they are about 0.14 to $0.16 \mathrm{~mm}$. in height; in the transverse, 0.18 to $0.20 \mathrm{~mm}$; in the descending colon, 0.22 to $0.25 \mathrm{~mm}$; in the sigmoid, 0.27 to $0.32 \mathrm{~mm}$.; while in the rectum, 0.27 to $0.36 \mathrm{~mm}$. In many places their apices are in close contact with each other, appearing as though fused. Iikewise, the glands show a more advanced stage of growth as the large intestine is followed downward. In the ascending colon they are scarcely visible; in the rectum they are very distinct. Except for this more advanced stage of development, conditions in the rectum are not so strikingly different from those in the remainder of the colon as at a former period. The epithelial cysts, while not so numerous, have not entirely disappeared. Those few which remain are smaller and are confined to the lower part of the rectum.

In an embryo of $99 \mathrm{~mm}$. the transverse colon shows numerous villi arranged in rows, 20 to 25 in number. As seen in figure 23, few distinct folds are present, but these do not occur in any definite relation to the villi, that is, the rows of villi and the folds are not alternately placed around the wall of the intestine. From this and from what I have seen in other embryos, it seems improbable that the new villi, which are now arising at a very rapid rate, are preceded by folds. More probably they develop after the mannor of the villi in the small intestinc, as separate growths between the villi already formed.

Numerous gland buds are also present in the specimen as shown in figure 23. Where the glands are cut in cross section, they show small but distinet lumina, surrounded by columnar cells of the mucous varicty, many of which are goblet, cells. On the tops and sides of the villi the epithelial cells are 0.022 to $0.028 \mathrm{~mm}$. in height while in the glands they are 0.034 to 0.042 
mm. Although shrunken from the underlying mesenchyma, the epithelial tube has increased to $1.03 \mathrm{~mm}$. in diameter. The sigmoid colon has a diameter of $0.95 \mathrm{~mm}$. and an epithelium which is similar in variety and of equal thickness to that just described.

From this point on, measurements taken of the glands and villi can only be considered approximately accurate. This is due to the fact that there is no sharp line of demarcation between gland and villus, consequently one is unable to determine just where the gland begins and where the villus leaves off. A similar difficulty was met with in the case of the small intestine. It is, however, possible, with the aid of models for comparison,

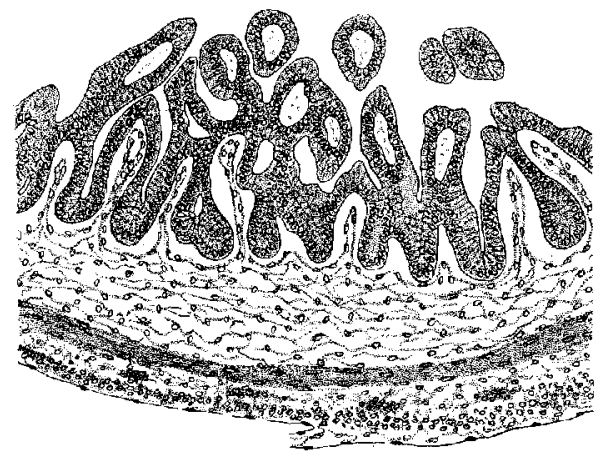

Fig. 5 Cross section of the transverse colon of a human embryo of $110 \mathrm{~mm}$. $\times 60$.

to judge the line of division approximately. In the following account of the growth of glands and villi, the figures given are the average of a number of measurements made from cross or longitudinal sections, or in some cases, from both. A more accurate method, which was cmployed whenever possible, was the direct measurement of these structures from the models themselves. In the transverse colon of the embryo under description $(99 \mathrm{~mm}$.), the glands may be regarded as about 0.07 $\mathrm{rmm}$. long and $0.056 \mathrm{~mm}$. broad, while the villi as $0.27 \mathrm{~mm}$. tall and $0.10 \mathrm{~mm}$. broad. In the sigmoid colon the glands average $0.10 \mathrm{~mm}$. and the villi $0.31 \mathrm{~mm}$. in length. 
In the transverse colon of an embryo of $110 \mathrm{~mm}$. (fig. 5), the villi are long and narrow, and give to the colon the appearance of a small intestine of a slightly older embryo. Some of them measure as much as 0.36 to $0.45 \mathrm{~mm}$. in length and average about $0.09 \mathrm{~mm}$. in diameter at their bases. They are covered by a low columnar epithelium (cuboidal in places), which is rather poor in goblet cells. The glands are longer than those of the preceding stage, being about 0.13 to $0.16 \mathrm{~mm}$. in length. The cells which line the glands are distinctly columnar, measuring from 0.022 to $0.028 \mathrm{~mm}$. in height. By far the majority of these are goblet cells. Their nuclei are basally placed and closely crowded together, making this region of the gland very deeply stained.

In the aseending colon, a similar picture is obtained. The villi are, however, somewhat shorter $(0.27$ to 0.36$) \mathrm{mm}$. Noticeable again is the greater distribution of goblet cells in the glands than on the villi, and the difference in the height of the epithelium in the two regions. In the sigmoid colon and the rectum, the epithelial tube is larger and flattened from side to side. The villi and glands are quite similar as regards size, shape and structure to those in the ascending colon. No epithelial cysts were found in the piece of rectum examined, which was a portion taken rather high up.

In a well preserved embryo of $120 \mathrm{~mm}$., the transverse colon has a diameter of about $1.08 \mathrm{~mm}$. in contrast to $1.26 \mathrm{~mm}$. in the preceding embryo. The villi, which are closely packed together, are also shorter $(0.18$ to $0.27 \mathrm{~mm}$.) than those of the former embryo, but the glands are of about the same length. This difference in size is probably due in part to the different proservating fluids used on the two embryos. The epithelium of both villi and glands is in excellent state of preservation and the goblet cells, which have taken the stain (orange-G) very strongly, stand out in marked contrast to the remaining cells. It is easily seen, therefore, that the goblet cells are more numerous on the sides than on the tops of the villi and most numerous in the glands. In many glands these cells appear to be exclusively present. Although the glands are still only short 
knoblike projections $(0.11$ to $0.14 \mathrm{~mm}$. in length and 0.09 $\mathrm{mm}$. in width), some of them appear to be double. As will be subsequently described, this bifurcating of the glands is a very important factor in their multiplication.

Conditions in the ascending colon, as regards villi and glands, are similar to those in the transverse. In the rectum the epithelial tube is again flattened laterally measuring $2.12 \mathrm{~mm}$. by $0.69 \mathrm{~mm}$. in cross section. The mucous membrane is thicker $(0.32$ to $0.36 \mathrm{~mm}$.) than that of the transverse colon $(0.27$ to $0.32 \mathrm{~mm}$.). Its villi are from 0.22 to $0.27 \mathrm{~mm}$. in height and its glands about the same as those found in the transverse colon (0.13 to $0.16 \mathrm{~mm}$.). Goblet cells are again very numerous. A few epithelial cysts were found in the extreme lower part of the rectum, but these were almost insignificant in size as compared to those of the former stages.

\section{Disappearance of villi}

In an embryo of $140 \mathrm{~mm}$. the transverse colon has a diameter of about $1.7 \mathrm{~mm}$. and presents from thirty-six to forty longitudinal rows of villi. It is apparent, therefore, that the villi are still increasing in numbers as the intestine is increasing in size. Since no distinct longitudinal folds can be found in either models or longitudinal sections, these additional villi must develop from the beginning as separate growths in the spaces between those villi already present. The form of the villi is shown in figure 24 . Some of the tallest measure only $0.25 \mathrm{~mm}$. in height. Disregarding the embryo of $120 \mathrm{~mm}$., because of the undoubted shrinkage of all its parts, and referring to the $110 \mathrm{~mm}$. stage, it is seen that the villi are shorter in the older embryo. Moreover, some of the villi are so short at $140 \mathrm{~mm}$. that the term villus is scarcely applicable to them, but whether these are newly developed villi or dwindled-down old ones, I am unable to determine. Although the intestinal glands vary in length $(0.13$ to $0.18 \mathrm{~mm}$.) they are on the whole slightly more advanced than before and many show signs of bilurcating. From the above observations it is evident that, as the glands are in- 
creasing in length, the villi are decreasing in height. In the subscquent stages of development, the villi become always lower and lower, so that it is now possible to say that the transitory villi reach their maximum height in embryos between $110 \mathrm{~mm}$. and $140 \mathrm{~mm}$., probably between $110 \mathrm{~mm}$. and $120 \mathrm{~mm}$.

In that portion of the ascending colon adjacent to the colic valve, shorter villi are found $(0.14$ to $0.18 \mathrm{~mm}$. in height $)$, which are also lower than those in the ileum $(0.27$ to $0.36 \mathrm{~mm}$.). Higher up in the ascending colon the villi are of about the same size, while the glands are 0.13 to $0.18 \mathrm{~mm}$. in length, and in the beginning of the ascending colon, a fow enlarged glands, such as are present in the vermiform process, are found. As regards villi and glands, the descending colon is quite similar to the transverse colon. In the sigmoid colon the villi are longer $(0.18$ to $0.27 \mathrm{~mm}$.$) ; in the rectum (0.18$ to $0.36 \mathrm{~mm}$.). Everywhere, however, the glands remain about the same length as those of the transverse colon. The epithelium is also quite similar throughout the whole colon. It is high columnar in the glands, lower on the sides, and lowest on the apices of the villi. Goblet cells are extremely numerous everywhere, being more abundant in the glands than on the villi.

\section{Effects of distention caused by a storing up of meconium}

$A$ marked difference in the thickness of the mucosa is found between the transverse colon of an embryo of $187 \mathrm{~mm}$. and that of the same portion of the intestine of an embryo of $190 \mathrm{~mm}$. (Compare figs. 6 and 7). That of the former is $0.36 \mathrm{~mm}$. in thickness, while that of the latter is only 0.16 to $0.20 \mathrm{~mm}$., the first being about twice the thickness of the second. The question arises, how is this variation to be accounted for? It is to be noted that the portion of intestine of the $190 \mathrm{~mm}$. embryo examined was filled with meconium, thereby extending its walls and increasing the size of its lumen. The total diameter of its epithclial tube is $4.2 \mathrm{~mm}$., in comparison to $2.3 \mathrm{~mm}$. in the $187 \mathrm{~mm}$. stage. These measurements show only that the epithelial tube is extended in the older stage, but they do not show 

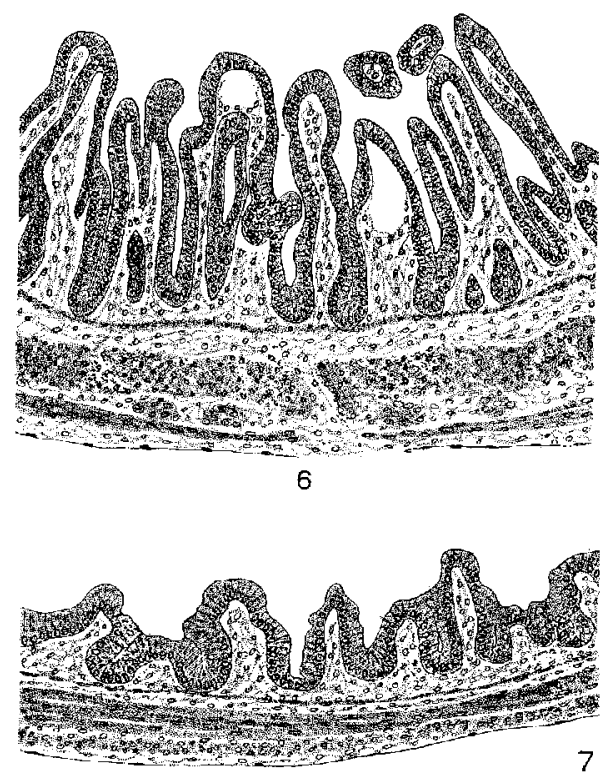

Fig. 6 Longitudinal section of the transverse colon of a human embryo of 187 $\mathrm{mm} . \times 60$. Shows state of normal contruction (compare villi and glands with those of fig. 7 ).

Fig. 7 Cross section of the transverse colon of a human embryo of $190 \mathrm{~mm}$. $\times 60$ (compare with fig. 6).

that the circumference of onc is greater in one than in the other, because in the younger stage the epithelial wall is thrown into three or four large folds. In order to determine accurately whether the folds alone would compensate for so great a difference in diameter, enlarged camera drawings were made, and the length of the lines at the bases of the glands (the line at which the muscularis is just beginning to appear) was measured. The distended gut $(190 \mathrm{~mm}$. stage $)$ measured $15.3 \mathrm{~mm}$., while the contracted one only $11.3 \mathrm{~mm}$., showing still a considerable unaccountable difference. From what $I$ have seen in this and other sections, in the small as woll as in the large intestine, I have come to the conclusion that wherever the cmbryonic intestine is greatly distended with meconium, as is often found to be the case in the older stages, the thickness of the mucosa 
becomes greatly reduced. In other words, where a considerable amount of meconium is found in the intestine, the thickness of its mucosa varies indirectly with the amount of distension.

Since the perimeters of the two colons under discussion were unequal in length, it is of interest to compare the number of glands present in them. This was done by counting the number of glands which were practically in contact with the developing muscularis mucosae. This method would not have given comparable results had not the thickness of the sections in both cases been the same ( 8 mierons). In the distended intestine variations from 79 to 96 and an average of 86 were obtained; in the non-distended piece, a variation from 81 to 91 and an average of 85.2 , showing that the number of glands is approximately the same. Whether the number of villi around the intestinal wall is the same in both of the intestines, is a harder problem to determine, owing to thcir greater size and irregularity in height, and to the fact that one is given no distinct basal line, as in the case of the glands, from which to measure. Such a problem could only be determined with any degree of accuracy by making a number of models of comparatively large areas. However, from cross sections alone, it is possible to make out that in the distended intestine the villi are further apart.

In the spreading or stretching out of the mucosa, both the villi and glands become reduced in length and broadened. The following measurements have been made to show this:

\begin{tabular}{|c|c|c|c|c|}
\hline & $\begin{array}{c}\text { FEEIGHT OF } \\
\text { TALLEST VILII }\end{array}$ & $\begin{array}{c}\text { WIITH OF } \\
\text { BASES OF VILT }\end{array}$ & LENGTH OF GLAYDS & WIDTH OF GLANDS \\
\hline & $m m$ & $m m$ & $m m$ & $m m$ \\
\hline Non-distended. . & $0.18 \cdots 0.27$ & $0.07-0.09$ & 0.22 & $0.05-0.09$ \\
\hline Distended...... & $0.00-0.09$ & $0.14-0.18$ & $0.11-0.14$ & $0.09-0.14$ \\
\hline
\end{tabular}

It must be noted that the villi had in many places practically disappeared.

The outer layers of the intestine are also reduced in thickness by distension, a fact which is of common observance in the digestive tube of the adult. In the non-distended transverse 
colon the submucosa, the muscularis, and the serosa together measure about $0.24 \mathrm{~mm}$., the distended one, $0.13 \mathrm{~mm}$.

From the above given figures, the effects of distention, caused by a storing up of meconium in the large intestine may be enumerated as follows: (1) an increase in the diameter of the epithelial tube; (2) an increase in the actual surface on which the basal ends of the glands lie; (3) a decrease in the thickness of the mucous membrane as a whole; (4) a decrease in the length of the glands and an increase in their width; (5) a more marked decrease in the height of the villi and an increase in their width (6) a spreading apart of the glands and of the villi; and (7) a decrease in thickness in the outer coats of the intestine.

The above results led to the question as to what effect distention would have upon the intestine of an adult. The small intestine of a guinea-pig was experimentally distended with normal salt solution and fixed and hardencd in that condition. Although the results of this and other experiments may be found in the following paper, it may be said here, that the results obtained are largely in accordance with those just described in the meconium-filled intestine of the human embryo.

Because of the above described effects of marked distention of the large intestine, it has been considered necessary, for the sake of comparison, to select only non-distended portions of the colon for modelling. In the ease of the embryo of $190 \mathrm{~mm}$. the sigmoid colon was chosen, for while this region contains meconium, there is no distention. This is made evident by the presence of longitudinal or oblique folds of the mucous mcmbrane, and by the following measurements as compared with those of the transverse colon of the same embryo: diameter of intestine $3.4 \mathrm{~mm}$; thickness of mucous membrane $0.34 \mathrm{~mm}$; thickness of outer intestinal coats, $0.23 \mathrm{~mm}$. Figure 22 shows the epithelium of this region of the intestine in surface view. The villi have dwindled down until they appear merely as irregular knobs which are joined together at their bases in the form of ridges. These ridges are of various lengths but all are of about the same thickness. They run in different directions and anastomose with one another, thus marking the surface of the 
epithelium up into an irregular network such as Langer ('87) has described in connection with the developing colic valve. The elefts in between the ridges are deep, and into them open the lumina of the intestinal glands. An examination of the basal surface of another model (not figured), from the same portion of the large intestine, shows numerous tubular glands, many of which are unbranched, but the branched type is not uneommon.

As stated before, the first beginnings of the intestinal glands appear as small knob-like processes which extend into the underlying mesenchyma. $\Lambda$ t the time they appear no muscularis mucosae is present. In embryos of $99 \mathrm{~mm}$., $110 \mathrm{~mm}$., $140 \mathrm{~mm}$., the muscularis mucosae is still not visible; nevertheless, the intestinal glands all reach a certain depth, so that in a section, a line drawn parallel to the surface of the mucous membrano would practically touch the bottoms of all the glands. It is along this line, or rather, slightly below it, that the muscularis mucosae is becoming visible in an embryo of $187 \mathrm{~mm}$. It is scen as a slight condensation of the mesenchyma forming a circular band of about $0.014 \mathrm{~mm}$. in thickness. In it are observable, though not very distinctly, developing myoblasts. The band is slightly more distinct at $190 \mathrm{~mm}$., and separates the connective tissue of the submucosa, which is condensed and well stained, from that of the tunica propria, which is loosely arranged and only faintly or not at all stained. At 187 and $190 \mathrm{~mm}$. the basal ends of the glands can be seen resting upon this layer of muscle.

\section{Further formation of glands}

As the glands are gradually increasing in number as the growth of the embryo proceeds, the question arises, how are new glands formed? Do they develop like new villi, by evaginations of the epithelium between those already formed, or are they developed after the manner which Patzelt has described, by a longitudinal splitting of those already present? In his discussion of this point Patzelt says: 
Noch erübrigt es mir, die Art und Weise anzugeben, wie sich die Lieberkühn'schen Drüsen vermehren. Bei der Durchsicht der Präparate, hauptsächlich aus den älteren Stadien, findet man oft im Grunde etwas verbreiterte Drüsen. In der Mitte des verbreiterton Grundes erhebt sich ein Epithelhöckerchen. Oft auch ist dieses Höckerchen nicht mehr blos aus Epithclzellen gebildet, sondern gleicht im Durchschnitte einem mit Epithel überkleideten Zöttchen, welches in das Innere der Drüsc hincinragt. Es entspricht dem Durchschnitte eines kleinen Fältchens, wolches den Grund der Drüse in zwei Theile spaltet. Dieses Fältchen wächst immer höher und höher. Dic Drüse hat endlich das Aussehen, als ob in einem gemeinsamen Vorraum zwei Drüsenschläuche mündeten (Fig. 29 e). Wenn schliesslich die Höhe des Fältchens in gleicher Ebene mit der Innenfläche des Darmes steht, ist der Theilungsprocess vollcndet, es sind aus einer Drüse zwei geworden.

He further believes that the upward growing conncctive tissue papilla continues its upward growth after it reaches the surface level and thus gives rise to a new villus.

In further support of Patzelt's view regarding gland multiplication may be mentioned that if new glands appeared as new outward growths from the epithelium, then one would expect to find always in any fetal intestine glands which extended for varying distances toward the muscularis mucosae. However, such an appearance is never found. The basal ends of the glands, as seen in figures $5,6,7,8,24$ and 25 , all extend down to one general level, no intermediate lengths being present. The branched types of glands are always present, some with two, some with three, and some with even four divisions. The amount of bifurcation also varies as Patzelt has figured. As in all problems of growing structures, it is indeed difficult to say precisely what changes are taking place, but I believe it safe to say that in this casc that additional glands are developed by a longitudinal splitting of those already present.

In the transverse colon of an embryo of $200 \mathrm{~mm}$. practically the same conditions as those described for the sigmoid colon of the $190 \mathrm{~mm}$. stage are cncountered. The mucous membrane, although not thrown up into folds, does not appear stretched out. The villi are of various sizes, the tallest being from 0.14 to $0.18 \mathrm{~mm}$. high. The intestinal glands mcasure from 0.18 to $0.22 \mathrm{~mm}$. in length. Other measurements taken are as follows: 


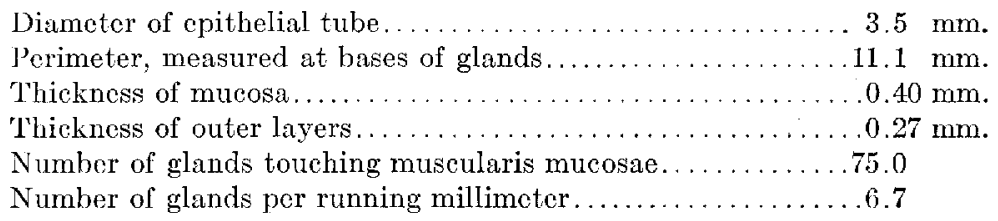

In the iliac colon of the same embryo, a slight distention is present as is indicated by the thickness of both the mucosa $(0.32 \mathrm{~mm}$.) and the outer layers $(0.18 \mathrm{~mm}$.). Although the preservation of the embryo is poor, enough can be made out from it to see that both villi and glands are shorter and broader than in the transverse colon.

In an embryo of $240 \mathrm{~mm}$. the transverse colon shows some distention, but not so much as was seen in this portion of the large intestine at $190 \mathrm{~mm}$. This is made evident by comparing the thicknesses of the mucosa and the outer coats. As seen in a model (not figured), made at double the magnification of the former model, the mucous membrane presents on its lumen surface a number of large irregular anastomosing folds. Between the folds are clefts, which in some places appear to be the glands themselves; in other places they are merely crypts into which the glands open. The glands are, for the greater part, of the simple tubular type, but some show bifurcations into two or three portions. The epithelium, which varies in thickness from 0.020 to $0.034 \mathrm{~mm}$., is made up of the typical simple columnar cells found in the adult intestine, and contains large numbers of goblet cells. The following list of measurements is given for comparison with the other stages:

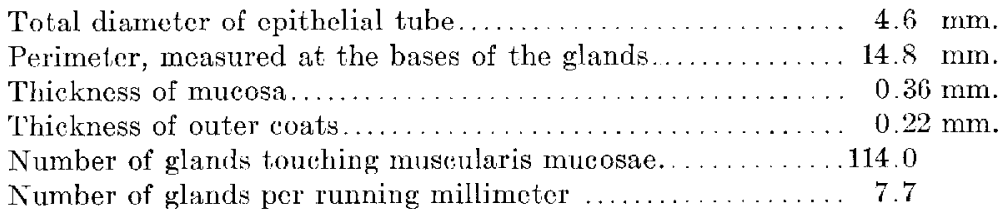

In an embryo of $320 \mathrm{~mm}$. a piecc of transverse colon which was greatly distended with meconium was examined. The large folds of the mucosa have all disappeared and the intestinal wall 
as a whole is considerably thinned out. Owing to poor preservation, however, it was not possible to determine the presence of villi and folds. Measurements made are as follows:

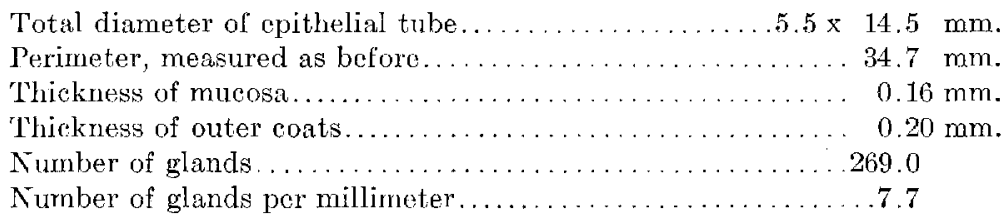

In a fetus of about seven months (premature birth) the ascending colon scems to be almost cntirely devoid of villi and the before-described folds. Although not modelled, it is plain to see that the surface epithelium is for the most part, though not entircly, level. At more or less regular intervals, it dips down into the cylindrical intestinal glands. Measurements:

Total diameter of epithelial tube................. $3.7 \mathrm{~mm}$.

Perimeter.................................. 18.5 mm.

Thickness of mucosa.......................... $0.27 \mathrm{~mm}$.

Thickness of outer coats...................... $0.54 \mathrm{~mm}$.

Number of glands........................... 162.0

Number of glands per millimeter.................. 8.7

Sections of the sigmoid colon show a similar condition as regards glands. They are of an equal length and similarly distributed.

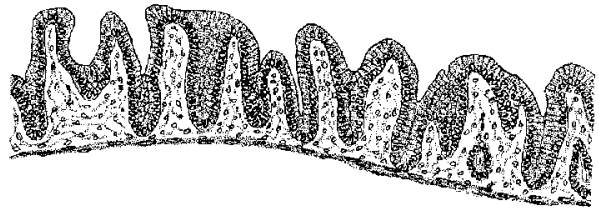

Fig. 8 Cross section of the mucosa of the transverse colon of a human embryo at birth. $\times 60$.

In a fully developed fetus at birth (fig. 8), a condition is reached in which the villi have entirely disappeared. A model of a portion of the epithelium of the transverse colon is shown in figure 25. As scen from the model, only glands are present, the openings of which appear irregular when viewed from the lumen 
side. For the most part the mouths of the glands open singly to the surface, but in one region of the model, three can be seen opening together in a slightly depressed region of the surface epithelium. The glands are still of the simple and bifurcated types, the bifurcated ones representing different stages in the process of splitting. The epithelium, which is similar to that in the adult, is $0.017 \mathrm{~mm}$. in thickness at the surface, while in the glands it measures $0.28 \mathrm{~mm}$. Goblet cells are still numerous. Measurements made from cross sections of the transverse colon at birth are as follows:

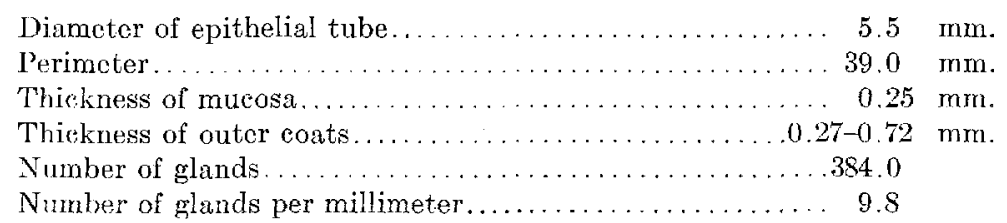

\section{Summary}

To the foregoing observations the following summary may be added. As has been pointed out before, the cylindrical tube of epithelium of the early stages develops longitudinal thickenings or ridges. In an cmbryo of $58 \mathrm{~mm}$. these are becoming partially transformed into low longitudinal folds. In embryos of $65 \mathrm{~mm}$. these folds apparently segment, and in embryos of 88 to $99 \mathrm{~mm}$. true villi are present. We have, therefore, longitudinal folds apparently subdivided to form villi. This view concerning the formation of the villi in the small intestine has been presented by Berry ('00) and confirmed by Forssner ('07). In opposition to this, the view that the villi arise as separate growths of the epithelium, not preceded by folds, has been maintained by Koelliker ('61 and '79), Barth ('68), and Brand ('77). Voigt (99) believed that the surface epithelium was cut up into a number of elevations by a net work of fissures and furrows, and that these elevations grew into villi. In a study of the development of the whole of the human small intestine the present author ('10) wrote: 
In briefly summarizing the development of villi, it may be said that the general tendency throughout the whole of the small intestine is for villi to develop as separate invaginations of the epithelium. Owing however, to the occurrence of transitory structures (vacuoles, diverticula, and folds) their development is manifested differently in different parts of the intestine.

Although in the large intestine formation of villi is preceded by distinct longitudinal folds, it does not seem probable to me, after a study of my models, that there is a mechanical segmentation of the longitudinal folds. It must be remembered that the epithelial tube is ever growing by an increase in the number of its cells, and by the enlargement and duplication of its parts. Because of this active growth one would expect, therefore, villi to form by an active direct process, rather than by an indirect one. It seems more probable to me, that small knob-like elevations are developed along the tops of the folds, and that these knobs form into villi. If such were the case, the picture presented would always be one which would appear like a segmentation of folds. As the villi grew taller and taller, the segmenting fissures would appear to be sinking in deeper and deeper. It is important in this connection to note that the original folds are considerably smaller than the villi, a fact which is in favor of the view just proposed. Regarding the further development of villi, it may be said with certainty, that they arise separately in between those already present.

The earliest glands develop as small knob-like growths of the epithelium into the mesenchyma. As has been pointed out before, the additional glands are probably formed by a longitudinal splitting of those already present.

The villi reach their maximum height in embryos of $110 \mathrm{~mm}$. to $140 \mathrm{~mm}$. in length. From this stage on they gradually become smaller and smaller. A fusion of adjacent villi together at their bases, which gradually extends towards their apices and lengthens the intestinal glands, has been described by Koelliker (61) and Schultze ('99) as the manner in which they disappear. Brand (77) describes the connective tissue about the glands as the active factor in their disappearance. He believes that 
the connective tissue gradually grows higher and higher, and in so doing, moulds the epithelium of the villi into that of the glands. Schirman ('98) describes the disappearance of the villi of the large intestine of the guinea-pig in an entirely different manner as follows:

Die embryonalen Zotten des Dickdarms bestehen beim Meerschweinchen zu vier Fünfteln ihrer Länge einzig aus Epithelzellen, nur das basale Fünftcl der Zotte enthält einen axialen, Blutgefässe führenclen Bindegewebstrang. Nur dieses basale Fünftel bleibt erhalten und geht in der Bildung der Lieberkühn'schen Drüsen auf, der grössere Rest wird zurückgebildet, er zerfällt.

It is certain that no such process as Schirman has described takes place in the human large intestine.

The disappearance of villi is indeed difficult to explain in mechanical terms. All that can be said with certainty is that the villi gradually develop, reach a certain maximum height, and then gradually fade out. It is of interest in this connection, however, to note that the effect of distention of the large intestine, caused by a storing up of meconium, brings about a disappearance, or at least a partial disappearance, of the villi. It is hardly probable that mechanical distention of this kind is connected with a lasting disappearance of villi of the large intestine, for they do not disappear permanently from the small intestine, where distentions are also found.

\section{Development of the plicae semilunares coli}

The before described longitudinal and oblique folds of the epithelium of the colon are in no way related to the later plicae semilunares. They disappear with the development of villi, and therefore, are only transient structures. The larger plicae semilunares are of later origin, and as they run an oblique course along the wall of the intestine, they have been studied from both cross and longitudinal sections. The observations shown in table 1, have been made to indicate the condition of the inner surface of the large intestine as regards these folds. 
TABLL 1

Showing the development of the plicae semitunares

\begin{tabular}{|c|c|c|c|c|}
\hline EMBRYO & ASCENDING COLOX & THANSVERSE COLON & $\begin{array}{l}\text { DESCENDING } \\
\text { COION }\end{array}$ & ILIAC COLON \\
\hline $\begin{array}{c}m m \\
65\end{array}$ & $\begin{array}{l}2 \text { large longitu- } \\
\text { dinal folds }\end{array}$ & $\begin{array}{l}3 \text { large longitud. } \\
\text { folds }\end{array}$ & None & \\
\hline 65 & $\begin{array}{l}2 \text { I argo and } 1 \\
\text { small longit. } \\
\text { fold }\end{array}$ & $\begin{array}{l}2-3 \text { very low } \\
\text { folds }\end{array}$ & None & None \\
\hline 70 & & $\begin{array}{l}\text { 1-2 large folds } \\
\text { somewhat obli- } \\
\text { que }\end{array}$ & $\begin{array}{l}1 \text { low broad } \\
\text { fold }\end{array}$ & \\
\hline 88 & $\begin{array}{l}3 \text { distinet longit } \\
\text { folds }\end{array}$ & 2-3 longit. folds & $\begin{array}{l}\text { Very low, but } \\
\text { broad circ. } \\
\text { folds, } 0.09 \\
\text { to } 0.13 \mathrm{~mm} \text {. } \\
\text { high }\end{array}$ & \\
\hline 99 & & 1-2 longit. folds & & \\
\hline 110 & $\begin{array}{l}\text { Slight indication } \\
\text { of folds }\end{array}$ & & & $\begin{array}{l}\text { Slight indication } \\
\text { of folds }\end{array}$ \\
\hline $\begin{array}{l}120 \\
140\end{array}$ & None & $\begin{array}{l}\text { None } \\
\text { Oblique folds, } \\
0.09 \mathrm{~mm} \text {. high, } \\
0.90 \mathrm{~mm} \text {. broad, } \\
0.07-0.14 \mathrm{~mm} \text {. } \\
\text { apart. }\end{array}$ & None & None \\
\hline 190 & & $\begin{array}{l}\text { None (intestine } \\
\text { distended) }\end{array}$ & & $\begin{array}{l}\text { Oblique folds, } \\
0.18-0.45 \mathrm{~mm} \text {. } \\
\text { high, } 0.27-0.36 \\
\text { mm. hroad, } 1.0- \\
1.6 \text { mm. apart. }\end{array}$ \\
\hline 240 & & $\begin{array}{l}\text { Oblique folds, } \\
0.09-0.27 \mathrm{~mm} \text {. } \\
\text { high, } 0.36-0.90 \\
\text { m m. broad, } \\
1.2-1.6 \mathrm{~mm} . \\
\text { apart. }\end{array}$ & & \\
\hline 320 & & $\begin{array}{l}\text { None (intestine } \\
\text { distended) }\end{array}$ & & \\
\hline $\begin{array}{l}7 \text { mos. } \\
\text { foetus }\end{array}$ & $\begin{array}{l}\text { Oblique folds, } \\
0.36-0.54 \mathrm{~mm} \text {. } \\
\text { high, } 0.36 \mathrm{~mm} \text {. } \\
\text { broad, } 0.7-1.3 \\
\text { mm. apart. }\end{array}$ & & & $\begin{array}{l}\text { Oblique folds } \\
\text { similar to those } \\
\text { in asccnding } \\
\text { colon. }\end{array}$ \\
\hline Birth & $\begin{array}{l}\text { Oblique folds, } \\
0.09 \mathrm{~mm} \text {. high, } \\
0.36-0.45 \mathrm{~mm} \text {, } \\
\text { broad, } 1.3-1.4 \\
\text { mm. apart }\end{array}$ & $\begin{array}{l}\text { Oblique fol } \mathrm{ds} \text {, } \\
1.3 \cdots 3.0 \mathrm{~mm} \text {. } \\
\text { high, } 0.36-0.54 \\
\mathrm{~mm} \text {. broad, } \\
\text { (seen in cross } \\
\text { sections only) }\end{array}$ & $\begin{array}{l}\text { Slight indica- } \\
\text { tion of oblj- } \\
\text { que folds }\end{array}$ & \\
\hline
\end{tabular}


From table 1 it would appear that the earlier longitudinal folds which develop before the $120 \mathrm{~mm}$. stage are lost. Later oblique folds are formed which, owing to their course, position, and constancy, must be the plicae scmilunares coli. These folds, however, are not present in portions of the large intestine which are distended, although the opposite view is held by some regarding those of the adult.

\section{THE VERMIFORM PROCESS}

\section{Early development}

The history of the mucosa of the vermiform process in the human embryo is quite similar to that of the colon. One finds first an epithelial tube with smooth walls and a round lumen. Later as the tube grows in size, folds appear. The folds give place to villi and glands develop. With the development of glands the villi disappear. Unlike the glands of the colon, however, those of the vermiform process of tentimes develop into cysts, which degenerate, and thus cause a decrease in the number of glands. In the following brief description, numerous references are made to the already described conditions of the large intestine.

The early development of the vermiform process has been described in connection with the carly stages of the colon. In the last-described stage $(42 \mathrm{~mm}$.) it is a simple tube of epithelium of about two to four cell nuclei in thickness, and presents on its inner surface three or four slight ridges. At $55 \mathrm{~mm}$. the epithelial tube is decidedly large near its base $(0.60 \mathrm{~mm}$.), but rapidly becomes smaller when followed towards its tip. The epithelium of the basal portion is thrown into ridges which resemble very much those of the ascending colon of the same embryo. A few vacuoles are present in some of the higher ridges. In the base of the vermiform process of an embryo of $58 \mathrm{~mm}$. (diameter only $0.40 \mathrm{~mm}$.) the epithelial ridges are more numerous They continue distalward for a short distance and gradually fade out. 
At $65 \mathrm{~mm}$. the base of the vermiform process measures 0.45 to $0.54 \mathrm{~mm}$. in diametcr. Its epithelium is now provided with distinct villi which resemble those found in the ileum and ascending colon of the same stage. Followed distalward the vermiform process becomes somewhat smaller, but even to its end, villi are present. In some places they appear to be forming from longitudinal folds. The epithelium is everywhere simple columnar and has a thickness ranging from 0.028 to $0.042 \mathrm{~mm}$. in thickness, depending whether measured on tops of the folds or between them. The large number of goblet cells present is striking, there being by far a greater number in the vermiform process than in the small or large intestine.

In an embryo of $88 \mathrm{~mm}$. the diameter of the vermiform process at its base is about $0.45 \mathrm{~mm}$. Numerous villi of about the same size as those in the lower part of the ilcum at this stage ( 0.25 to $0.27 \mathrm{~mm}$. in height) are found. The glands have begun to appear and in places where they are cut in cross section they show small round lumina. Toward its tip the villi are distinct, but shorter $(0.11 \mathrm{~mm}$. high). Some are in the form of longitudinal folds (fig. 26). Glands are in most places very small, but their beginnings are everywhere visible.

The epithelial tube of the base of the vermiform process in an embryo of $110 \mathrm{~mm}$. has a diameter of about $0.70 \mathrm{~mm}$. Both glands and villi are distinct, but the former are as yet very rudimentary. In most places they are, as well as can be determined from cross and longitudinal sections, 0.09 to $0.11 \mathrm{~mm}$. in length. The villi are shorter than those found in the base of the vermiform process of the preceding stage, being only 0.14 to $0.16 \mathrm{~mm}$. in height. Goblet colls are again very numerous. The distal end has a diameter of $0.77 \mathrm{~mm}$., being slightly greater than its proximal portion. The villi are again shorter $(0.11$ to 0.13 mm.) than those found above, but somewhat longer than those found in the same portion of the vermiform process of the preceding embryo. The glands are approximately the same length as before. The extreme tip is rounded in shape, and is provided with villi and glands of the same type as those on the side walls. 


\section{Enlarged glands and gland cysts}

In an embryo of $140 \mathrm{~mm}$. the epithelial tube of the caecum is $1.4 \mathrm{~mm}$. in diameter, and its villi $0.18 \mathrm{~mm}$. to $0.27 \mathrm{~mm}$. high. For the most part the glands are 0.09 to $0.13 \mathrm{~mm}$. in length and 0.054 to $0.072 \mathrm{~mm}$. in width. Some of the glands, however, are swollen at their lower ends, being from $0.09 \mathrm{~mm}$. to 0.13 $\mathrm{mm}$. in diameter. They are all supplied with lumina, which in the enlarged glands are occluded at the necks of the glands. More distally, the base of the vermiform process has a diameter of only $0.9 \mathrm{~mm}$. The villi are similar to those of the caecum, and the bulbous glands are more numerous. Still more distally, near the tip of the vermiform process, the villi are shorter $(0.14$ to $0.16 \mathrm{~mm}$.), and the cnlarged glands are found in still greater numbers. Figure 27, from a model of the epithelium of the tip shows some of these glands. Many have enlarged ends connected with the surface epithelium by constricted necks. The gland marked in the figure is the only gland which could be found which is entirely cut off from the surface epithelium. From serial sections, it is possible to make out that although the bulb-like expansions are provided with decidedly large lumina, these are totally cut off from the lumen of the vermiform process. Moreover, the cells of the necks of the glands appear to be undergoing degenerative changes. In many places only a slight strand of tissue, largely composed of epithelial cell nuclei, could be found connecting the bulb with the surface epithelium.

In the vermiform process of an embryo of $170 \mathrm{~mm}$. the enlarged glands are very numerous. Owing, however, to poor preservation it is impossible to state whether they are connected with the surface or not. In the connective tissue of the submucosa can now be seen distinct nodules of lymphoid tissue.

Sections through the base of the vermiform process of an embryo of $190 \mathrm{~mm}$. shows ill-marked villi, 0.07 to $0.11 \mathrm{~mm}$. in height and of variable width. The glands, now $0.11 \mathrm{~mm}$. to $0.16 \mathrm{~mm}$. long, are more regular and only a few tend to be bulbous. The condition found is quite similar to that of the sigmoid colon of the same embryo with the difference that there are 
fewer glands present. For the first time, the muscularis mucosae becomes visible, and the glands in places pierce it. In the tip of the vermiform process the epithelial tube is expanded to a diameter of $1.7 \mathrm{~mm}$., in comparison to $0.6 \mathrm{~mm}$. at its base. The villi have practically disappeared, only very slight elevations being left in places. The glands are similar in form, but farther apart than those of the base. In places the muscularis mucosac can be seen, but it is not well differentiated as yet.

In an embryo of $200 \mathrm{~mm}$. the epithelial tube of the base of the vermiform process (fig. 28), although its diameter is about the same $(1.6 \mathrm{~mm}$.), is quitc different from that of the preceding stage. The villi have almost everywhere entirely disappeared. The glands are of various size, some of the swollen ones being 0.13 to $0.14 \mathrm{~mm}$. broad. Most of these extend down only to the muscularis mucosae, others have pushed into it and cause it to bulge outward, while still others have pierced it. In some places the swollen ends of glands appear as cysts, entirely cut off from the surface epithelium (figs. 10 and 28). Some cysts appear to be entirely surrounded by a thin stratum of smooth muscle derived from the muscularis mucosae. The epithelium lining the cysts shows various stages of degeneration. In some it appears almost similar to the surface epithelium. In others only that part of the epithelium lining the base of the cyst is similar to that of the surface, while the upper portion, that is, that portion of the cyst which had formerly been the neck of the gland, has an epithelium which is much thinner and composed largely of broken down nuclei and fragments of cell protoplasm. In other cysts, degeneration has involved all the cells of the epithelium, but those in the upper end again show a more advanced stage of deterioration. Still other cysts are of smaller size and have their epithelia reduced to a thin line.

Stöhr ('98) and Nagy ('11) found epithelial cysts of the kind described in the vermiform process of human embryos. According to Stöhr the epithelium of the cut off glands becomes poorer and poorer in goblet cells and bcgins to degencrate. The cyst itself becomes filled with degenerative products, and as the epithelium gradually goes to pieces the walls collapse. $\mathrm{He}$ 


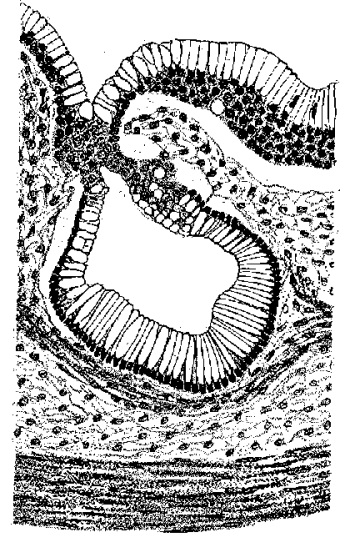

9

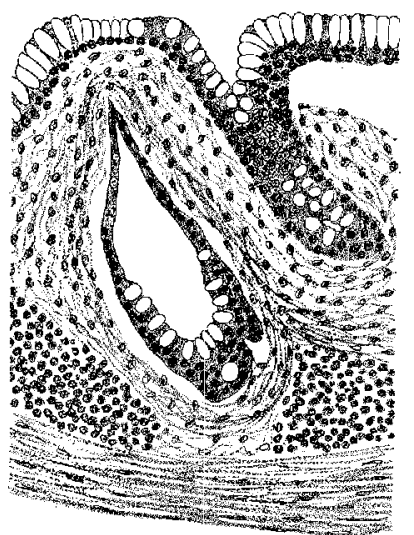

10

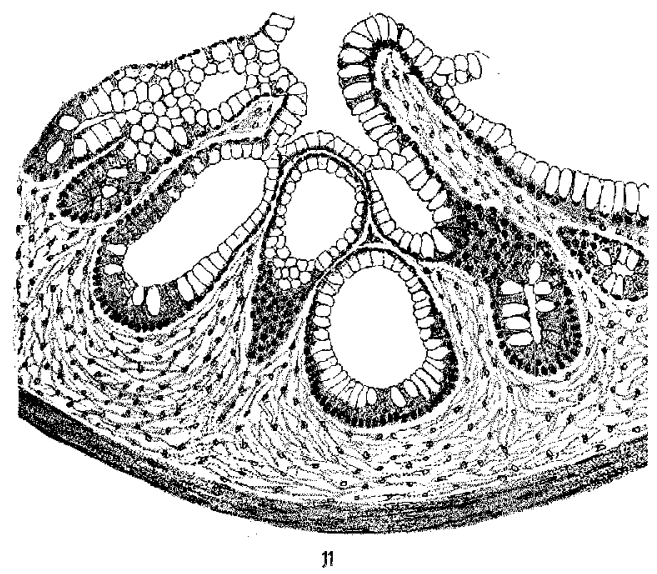

Figs. 9 and 10 Cross sections of the murosa of the vermiform process (including the circular layer of the muscularis). Human embryo of $200 \mathrm{~mm}$. $\times 120$. In figure 19 is shown a gland cyst not entirely cut off from the surface epithelium. In figure 10 is shown a cyst detached from the surface cpithelium and undergoing degenerative changes.

Fig. 11 Mucosa of the rectum (including the circular layer of the muscularis) in cross scction. Human embryo of $65 \mathrm{mmn} . \times 120$. Shows several epithelial gland cysts. 
concludes: "Als letzten Rest der Drüse findet man dann minimale, 0.05-0.15 mm. messende Gruppen kleiner Isithelzellen, die von einer dicken bindegewebigen Kapsel (Fig. 19a) umgeben sind."

Numerous and distinct lymphoid nodules are present in the vermiform processes of all the embryos from $170 \mathrm{~mm}$. up, but never, so far as I have obscrved, are the cysts located in them. I agree with Stöhr when he says: "Der Verfolg der Serie zeigt immer, dass die reducirten Drüsen nur am Rande des Knötchens liegen, zuweilen sogar in dessen Peripherie hineingepresst sind. Das Centrum der Knötchen enthält keine reducirten Drüsen."

Moreover, such a degeneration of glands is not found in other portions of the large intestine where lymphoid nodules are plentiful. It is not probable, therefore, that the development of lymphoid tissue has anything to do with the formation and degeneration of these cysts.

There are no marked changes in the form of the mucosa of the vermiform process in the subsequent stages of development. At $240 \mathrm{~mm}$. villi, bulbous glands, and cysts have entirely disappeared. The glands, as seen in figure 29, are small and rather widely separated. The muscularis mucosac is distinct and occasionally glands can be seen which have pierced it.

In specimens at seven months, birth, and a two wecks old child, practically the same conditions are found. Lymphoid tissue, both in the diffuse and nodular form, is abundant. The statement made by Bcrry and Lack ('06) that "In the vermiform appendix of the full term feotus there is practically no lymphoid tissue, or at least so little as to constitute a negligible quantity, whilst lymphoid follicles are absent," cannot be confirmed. 


\section{CONCLUSIONS}

1. The large intestine, like the oesophagus, stomach, and small intestine, is at first a simple tube of epithelium, and is the last portion of the digestive tube to show distinctive changes in the form of its mucosa. The first change which occurs is the formation of longitudinal folds and ridges.

2. The ridges and folds first appear in the rectum and then extend upward (orally). A second point of growth is found in the ascending colon at the colic valve. The direction of growth here is in the opposite direction (aborally). The transverse colon is the last portion of the large intestine to develop ridges and folds.

3. A few vacuoles similar to those found in the oesophagus, stomach, and small intestine, are found in the epithelial wall of the large intestine in its early stages.

4. The longitudinal folds are replaced by villi in a manner which suggests a segmenting of folds. However, it is not improbable that the villi of the large intestine arise after the manner of those of the small intestine, as separate growths along the tops of the folds.

5. Additional villi arise as separate growths between those villi already formed, not being preceded by folds.

6. The first glands appear as knob-like protuberances of the epithelium into the underlying mesenchyma. Additional glands develop by a splitting, from below upwards, of thosc already formed.

7. Villi reach their maximum height in cmbryos between 110 $\mathrm{mm}$. and $140 \mathrm{~mm}$. in length. From this time on they gradually become smaller in size. Remnants of them persist as folds which form an irregular network in between the gland openings. 'They are entirely' gone at birth.

8. In the vermiform process villi and glands develop, and the villi disappear at the same time and in the same manner as those of the ascending colon.

9. Enlarged and cystic glands are found in the vermiform process and caecum. Many of them become detached from the 
surface epithelium and are then entirely surrounded by connective tissue. They later disappear by degeneration and absorption. Lymphoid nodules are found in abundance in the vermiform process at birth, but the cysts never lie in the centers of them.

10. Epithelial cysts are also found in the mucosa of the rectum. They are in many ways similar to those found in the vermiform process, but differ from them in that they are not so deeply seated in the tunica propria, are seldom entirely detached from the surface epithelium, and disappear not by degeneration and absorption, but by breaking through into the intestinal lumen.

11. Distention of the large intestine, due to the accumulation of meconium, brings about marked changes in the form of the mucosa. It reduces its thickness, broadens and shortens both villi and glands, and causes them to become spread apart.

\section{BIBLIOGR $A P H Y$}

Batinsky, A. 1882 Untersuchungen über den Darmkanal des menschlichen Kindes. Areh. f. path. Anat., Bd. 89, pp. 64-94.

Barth 1868 Beiträge zur Entwickelung der Darmwand. Sitzungsb. d. Wien. Akad. d. Wissensch., Bd. 58, pp. 128-136.

Brerry, J. M. 1900 On the development of villi in the human intestine. Anat. Anz., Bd. 17, pp. $242-249$.

BerRy, R. J. A., ANd LACK, L. A. H. 1906 The vermilorm appendix of man, and the struetural ehanges therein coincident with age. Jour. Anat. Physiol., vol. 40, pp. 247-256.

Brand, E. 1877 Beiträge zur Entwickelung der Magen- und Darmwand. VerhandI. d. phys. -mod. Gesellsch. zu Würzb., Bd. 9, pp. 243-25̈6.

Johrson, F. P. 1910 'The development of the mucous membrane of the oesophagus, stomach, and small intestine in the human embryo. Am. Jour. Anat., vol. 10, pp. 521-561.

Íопцiкk, A. 1861 Entwickelungsgeschichte des Menschen und der höheren Thiere. Leipzig. 1879 Ibid. 2e Aufl.

LANGER, C. yon 1887 Tjeber das Verhalten der Darmschlcimhaut an der Mliocoecal-Kilappe, nebst Bemerkungen über ihre Entwicklung. Denkschriften d. k. Akad. d. W. math.-naturw. Classe, Bd. 54, Abt. 1, pp. $5 \mathrm{I}-58$.

Lewis, F. T, 1911 Die Entwisklung des Diekdarms. IIandbush der Entwicklungsgeschichte des Menschen, herausgegeben von Keibel und Mall. Bd. 2, siebzehntes Kapitel, pp. 382-391. 
NAGY, L. v, 1911 Ueber die Histogenese des Darmkanals bei menschlichen Embryonen. Anat. Anz., Bd. 40, pp. 147-156.

Patzelt, V. 1883 Ueber die Entwicklung der Dickdarmschleimhaut. Sitzungsb. d. k. Akad. d. Wissensch. Wien. Bd. 86, pp. 145-172.

Schinman, D. 1898 Ueber die Rückbildung der Dickdarmzotten des Meerschweinchens. Verhandl. d. phys.-med. Gesellsch. z. Würzb., N. F., Bd. 32, pp. 1-9.

Schultze, O. 1899 Grundriss der Entwickclungsgeschichte des Menschen und der Säugethiere. Leipzig.

Sтӧнг, P. 1898 Ueber die Lintwicklung der Darmlymphknötchen und über die Rückbildung von Darmdrüsen. Arch. f. mikr. Anat., Bd. 51, pp. $1-55$.

Vorgt, J. 1899 Beitrag zur Entwickelung der Darmschleimhaut. Anat. Hefte, Abt. 1, Bd. 12, pp. 49-70.

\section{PLATE 1}

\section{EXPLANATION OF FIGURES}

12 Wax reconstruction of the epithelium of the ascending colon. Human embryo of $50 \mathrm{~mm} . \quad \times 89$.

13 Wax reconstruction of the epithelium of the transverse colon. Human embryo of $50 \mathrm{~mm}$. $\times 89$.

14 Wax reconstruction of the epithelium of the descending colon. ITuman embryo of $50 \mathrm{~mm} . \quad \times 89$.

15 Wax reconstruction of the epithelium of the ascending colon (portion near the colic valve). Human embryo of $58 \mathrm{~mm} . \times 89$.

16 Wax reconstruction of same. More caudad portion. $\times 89$.

17 Wax reconstruction of the epithclium of the transverse colon. Human embryo of $58 \mathrm{~mm} . \times 89$.

18 Wax reconstruction of the epithelium of the descending colon. Human embrya of $58 \mathrm{~mm} . \times 89$. 


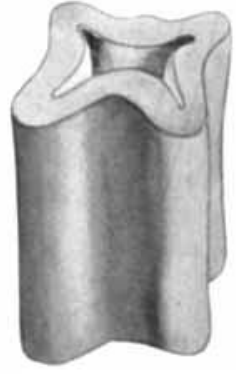

Fiij. 12

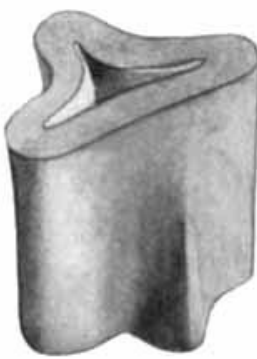

Fï. 1.3

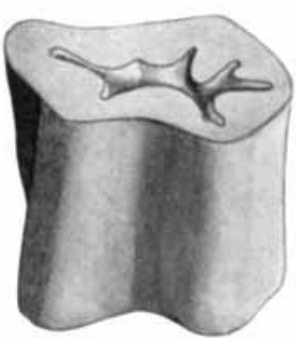

Fig. 14

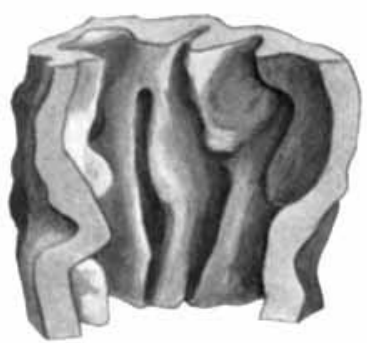

Fig. 1.5

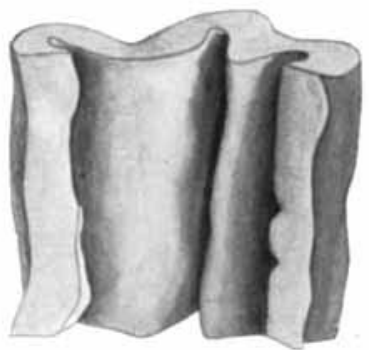

Fig. 17

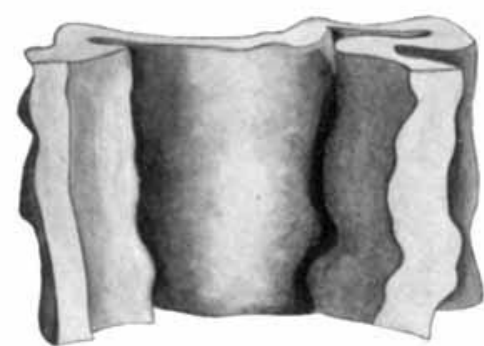

Fig. 16

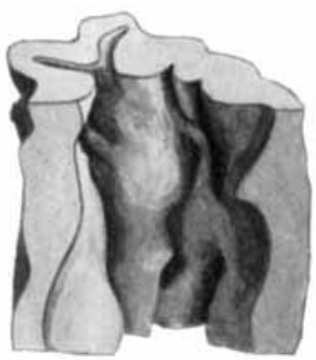

Fig. 18 


\section{PLATE 2}

\section{EXPLANATION OF FIGTRES}

19 Wax reconstruction of the epithelium of the upper part of the rectum. Human embryo of $58 \mathrm{~mm} . \times 89 ; x$, epithelial gland cyst.

20 Wax reconstruction of the epithelium of the transverse colon. Human embryo of $65 \mathrm{~mm} . \times 89$.

21 Wax reconstruction of the opithelium of the descending colon. Iruman embryo of $65 \mathrm{~mm}$. $\times 89$.

22 Wax reconstruction of the epithelium of the sigmoid colon. Ifuman embryo of $190 \mathrm{~mm}, \quad \times 89$. 


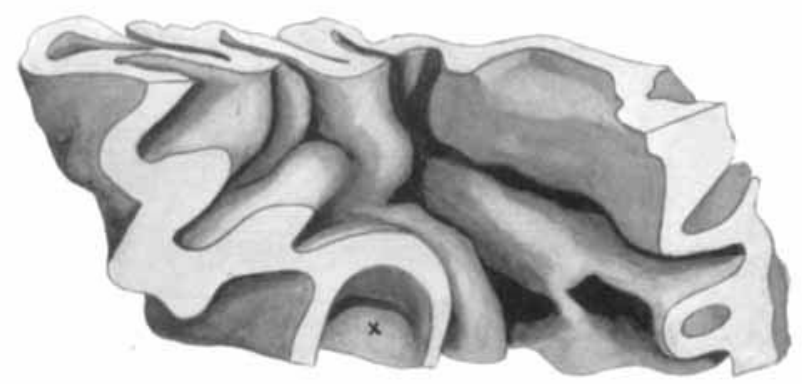

Fig. 19

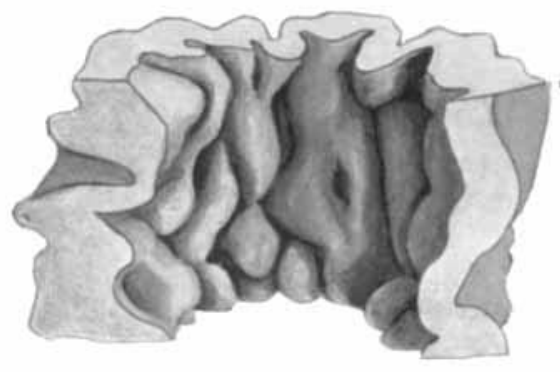

Fig. 20

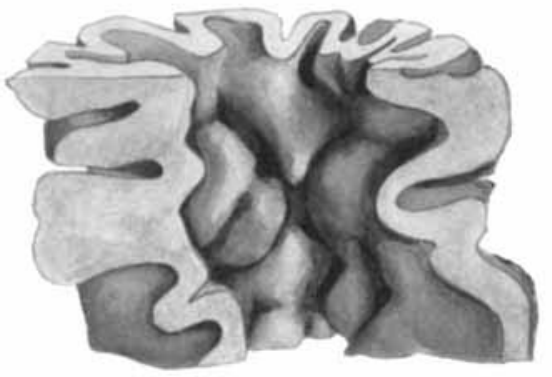

Fig. 21

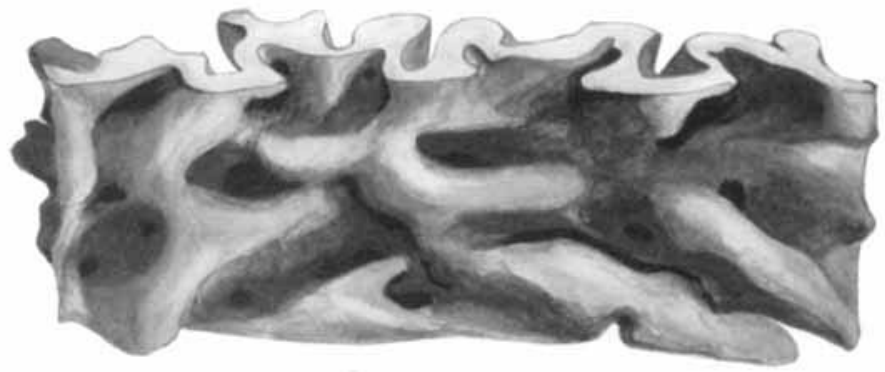

Fig. 22 


\section{PLATE 3}

EXPLANATION OF FIGURES

23 Wax reconstruction of the epithelium of the transverse colon. Human embryo of $99 \mathrm{~mm}$. $\times 89$.

24 Wax reconstruction of the epithelium of the transverse colon. Human embryo of $140 \mathrm{~mm} . \quad \times 89$.

25 Wax reconstruction of the epithelium of the transverse colon. Human embryo at birth. $\times 178$. 


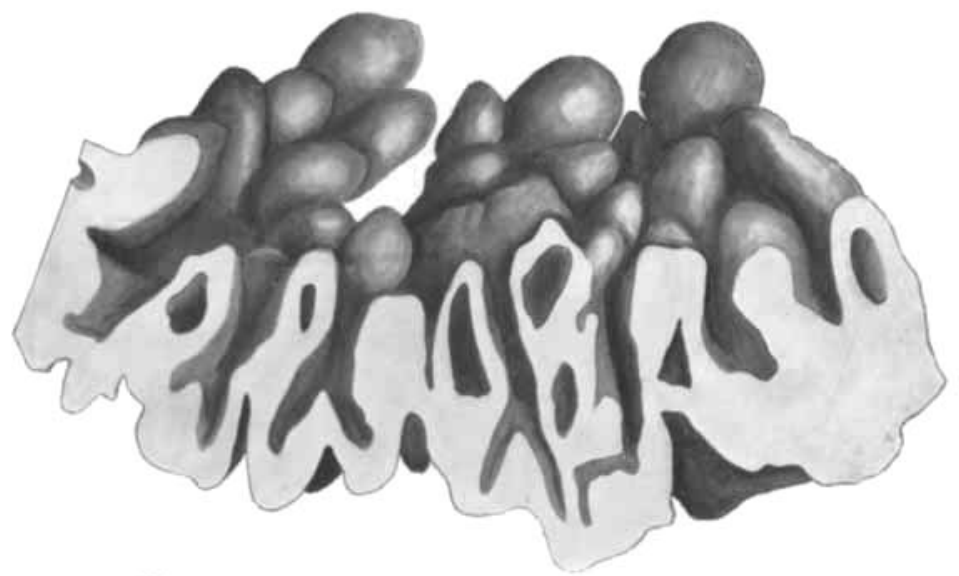

Fig. 2.3
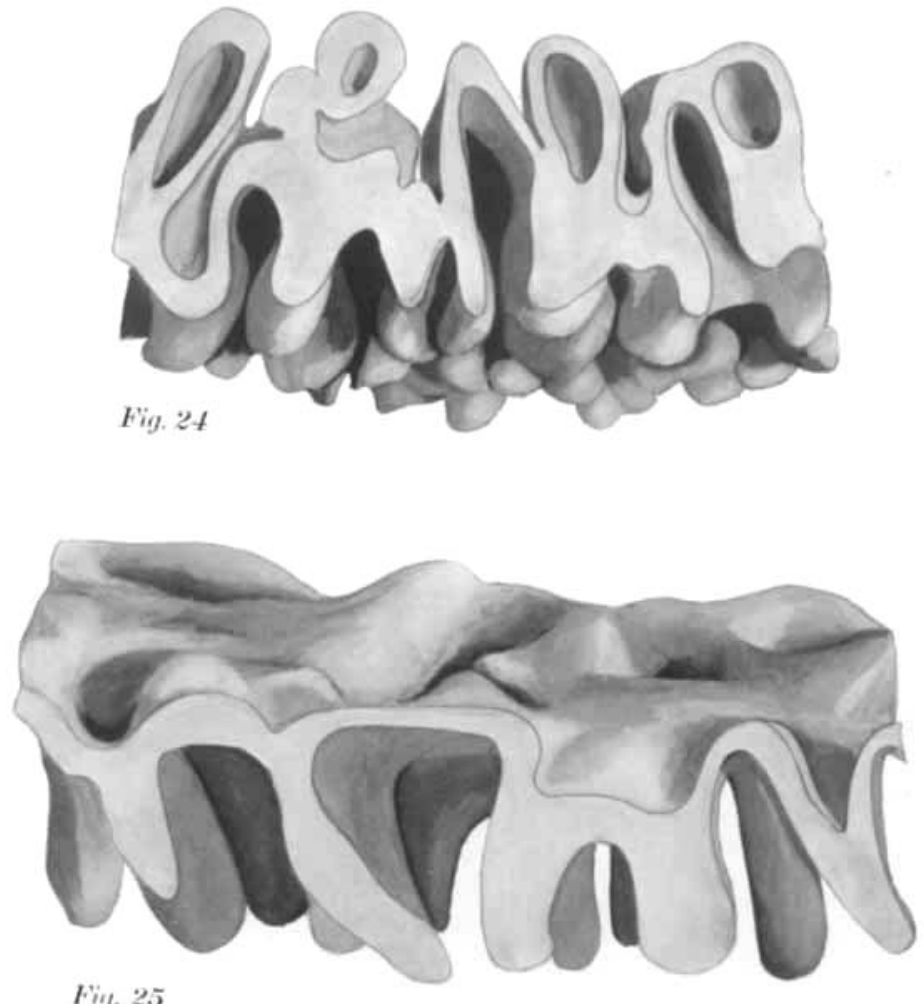
PLATF 4

EXPLANATION OF FIGURES

26 Wax reconstruction of the epithelium of the tip of the vcrmiform process. Human embryo of $88 \mathrm{~mm} . \times 89$.

27 Wax reconstruction of the epithelium of the lip of the vermiform process. Human embryo of $140 \mathrm{~mm} . \times 89 ; x$, epithelial gland cyst, entircly cut off from surface epithelium.

28 Wax reconstruction of the epithelium of the base of the vermiform process. Human embryo of $200 \mathrm{~mm}$. $\times 89 ; x$, epithelial gland eyst, entirely cut off.

29 Wax reconstruction of the epithelium of the tip of the vermiform pracess. Human cmbryo of $240 \mathrm{~mm} . \times 89$. 
FRANKLIN PARADIRT JOHNSON

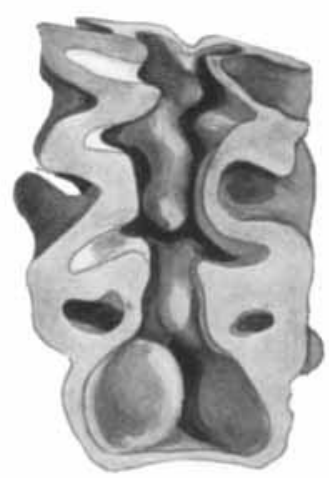

Fig. 26

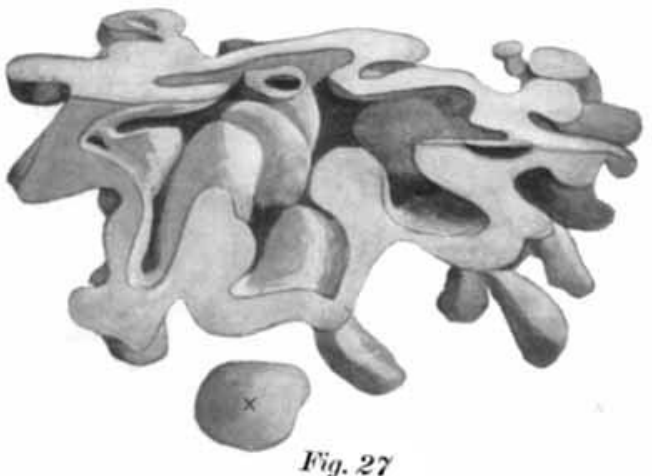

Fig. 27

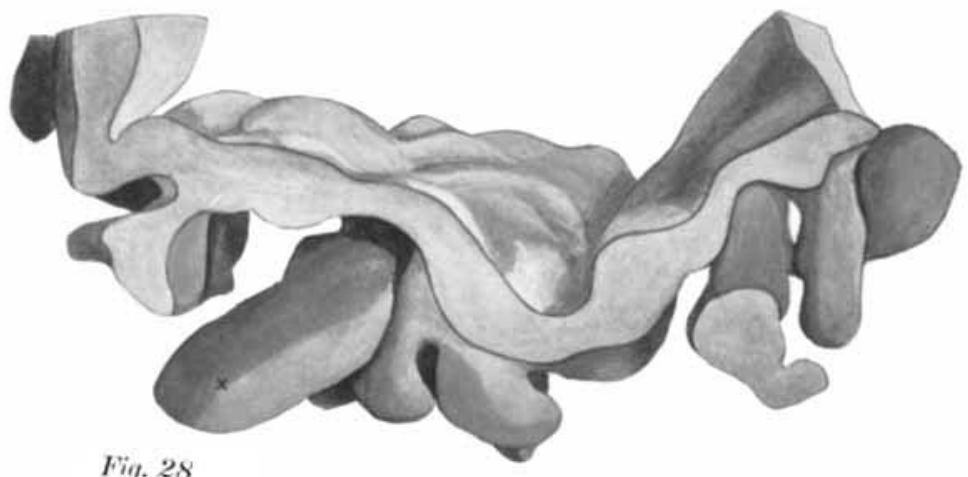

Fig. 28

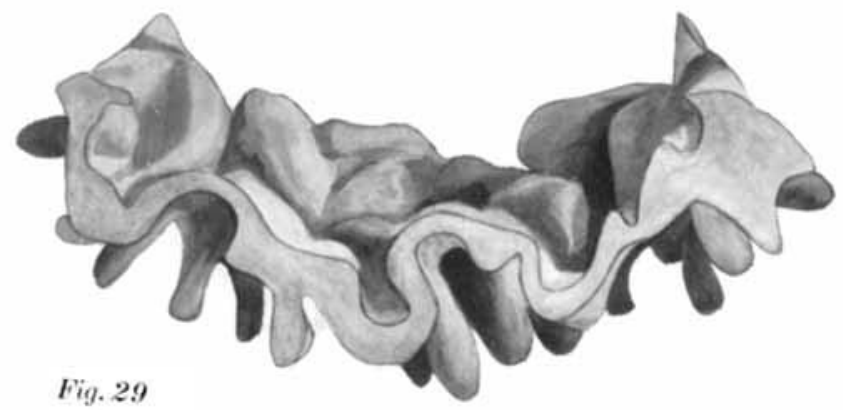

